\title{
Glassy-Winged Sharpshooter (suggested common name), Homalodisca coagulata (Say) (Insecta: Hemiptera: Cicadellidae: Cicadellinae) ${ }^{1}$
}

Tracy Conklin and Russell F. Mizell, $\mathrm{II}^{2}$

\section{Introduction}

The glassy-winged sharpshooter, Homalodisca coagulata (Say), is a large leafhopper species native to the southeastern United States. It is one of the main vectors of the bacterium Xylella fastidiosa, a plant pathogen that causes a variety of plant diseases, including phony peach disease of peach and Pierce's disease of grape. Though usually not a serious pest in the area of its native distribution, the glassy-winged sharpshooter has recently been introduced into southern California, where it has become a serious threat to viticulture due to its ability to vector Pierce's disease.

\section{Distribution}

Turner and Pollard (1959) describe the range of $H$. coagulata as a strictly southern species, abundant from the latitude of Augusta, Georgia to Leesburg, Florida, having a western boundary of ValVerde and Edwards counties in Texas. Current distribution data shows that the sharpshooter is present to some extent in south Florida as well. Sorensen and Gill (1996) note that the range of $H$. coagulata has extended to include several counties in southern California, most likely having been introduced to the state through the nursery industry. The map of California (courtesy of the California Department of Agriculture) shows the current distribution of the glassy-winged sharpshooter in southern California and the counties at risk of infection.

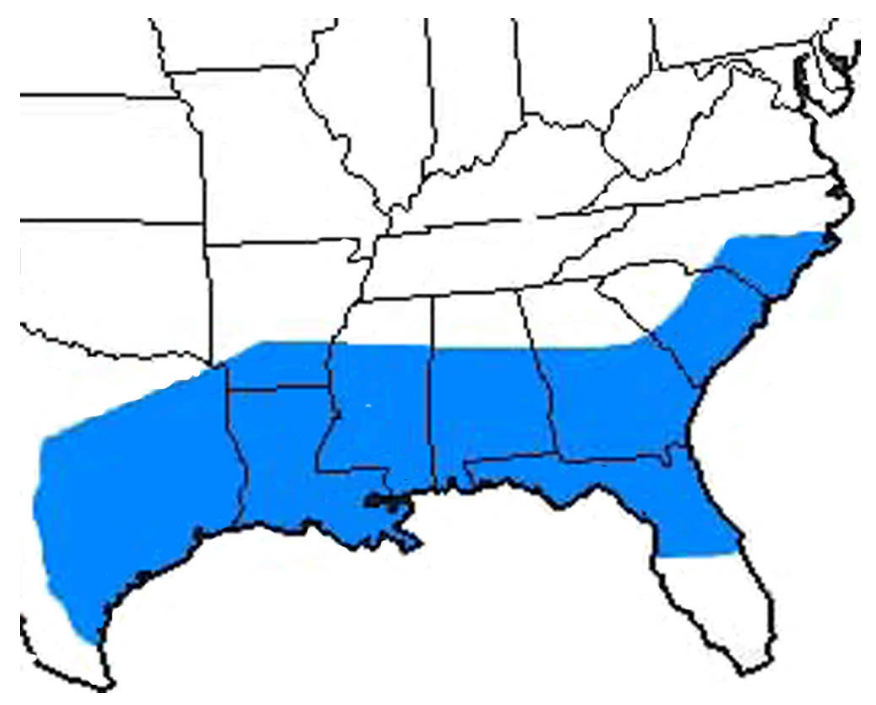

Figure 1. Distribution of the glassy-winged sharpshooter, Homalodisca coagulata (Say), in the southeast United States. Credits: Tracy Conklin, University of Florida

1. This document is EENY-274, one of a series of Featured Creatures from the Entomology and Nematology Department, Florida Cooperative Extension Service, Institute of Food and Agricultural Sciences, University of Florida. Published: October 2002. Revised: July 2004. This document is also available on Featured Creatures Website at http://creatures.ifas.ufl.edu. Please visit the EDIS Website at http://edis.ifas.ufl.edu.

2. Tracy Conklin and Russell F. Mizell, III, Department of Entomology and Nematology, University of Florida.

The Institute of Food and Agricultural Sciences (IFAS) is an Equal Employment Opportunity - Affirmative Action Employer authorized to provide research, educational information and other services only to individuals and institutions that function without regard to race, creed, color, religion, age, disability, sex, sexual orientation, marital status, national origin, political opinions or affiliations. For information on obtaining other extension publications, contact your county Cooperative Extension Service office. Florida Cooperative Extension Service / Institute of Food and Agricultural Sciences / University of Florida / Larry R. Arrington, Interim Dean 


\section{Distribution of GWSS in California}

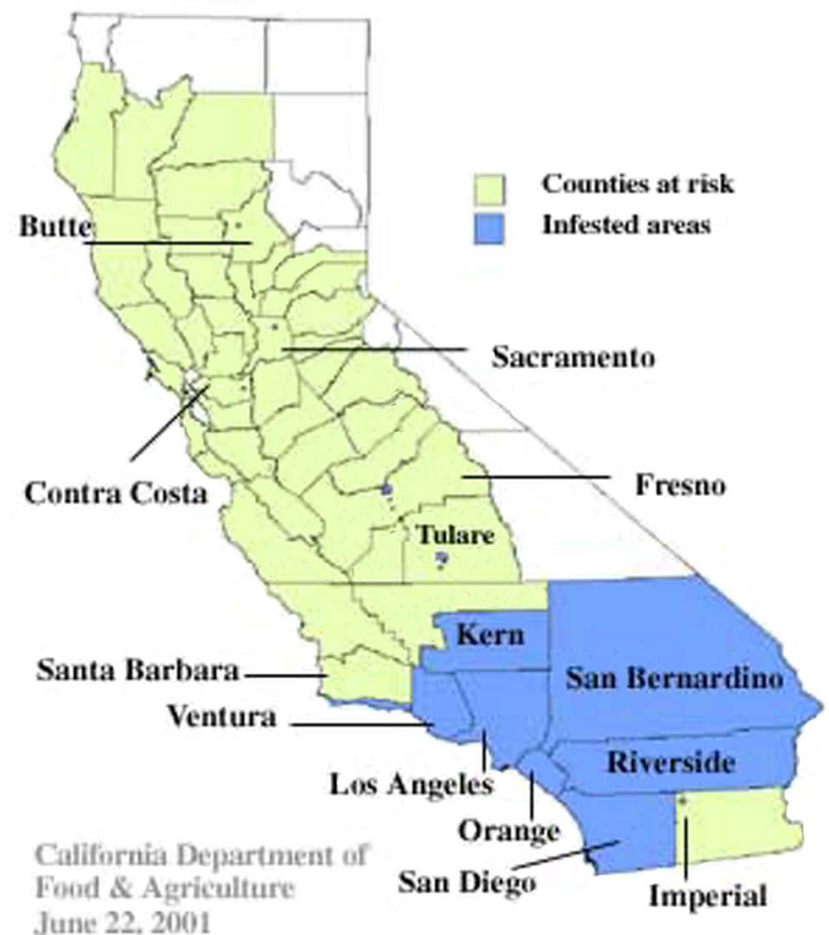

Figure 2. Distribution of the glassy-winged sharpshooter, Homalodisca coagulata (Say), in California. Credits: California Department of Agriculture

\section{Description}

The glassy-winged sharpshooter measures 1.5 to $2 \mathrm{~cm}$, mostly brown-colored on the dorsal side, with ivory and black markings under the abdomen. Glassy-winged sharpshooters have large smokybrown wings with red markings and are very good flyers, making them able to transmit plant diseases further than other vector leafhoppers such as the blue-green leafhopper (Graphocephala atropunctata (Signoret)). The face and legs of the glassy-winged sharpshooter are yellow-orange in color. Nymphs are wingless and gray, having a body shape similar to the adults.

\section{Life Cycle}

The female glassy-winged sharpshooter lays her eggs in groups of three to 28 eggs just under the epidermis layer of several well-chosen leaves. Preferred plants for oviposition may include holly, sunflower and citrus. Strict nutrient requirements for young nymphs are believed to be important factors in the choice of plants for oviposition. As the female

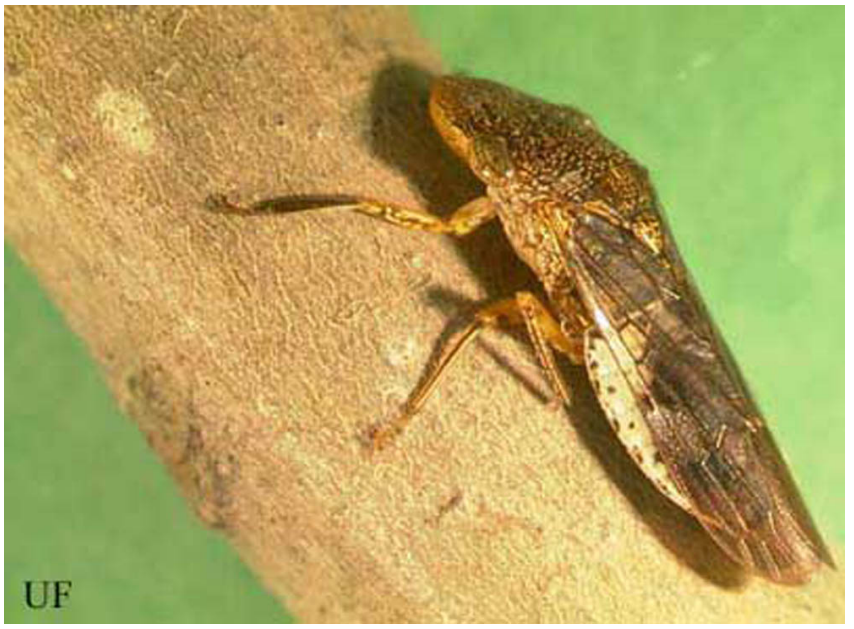

Figure 3. Adult glassy-winged sharpshooter, Homalodisca coagulata (Say). Credits: Tracy Conklin, University of Florida

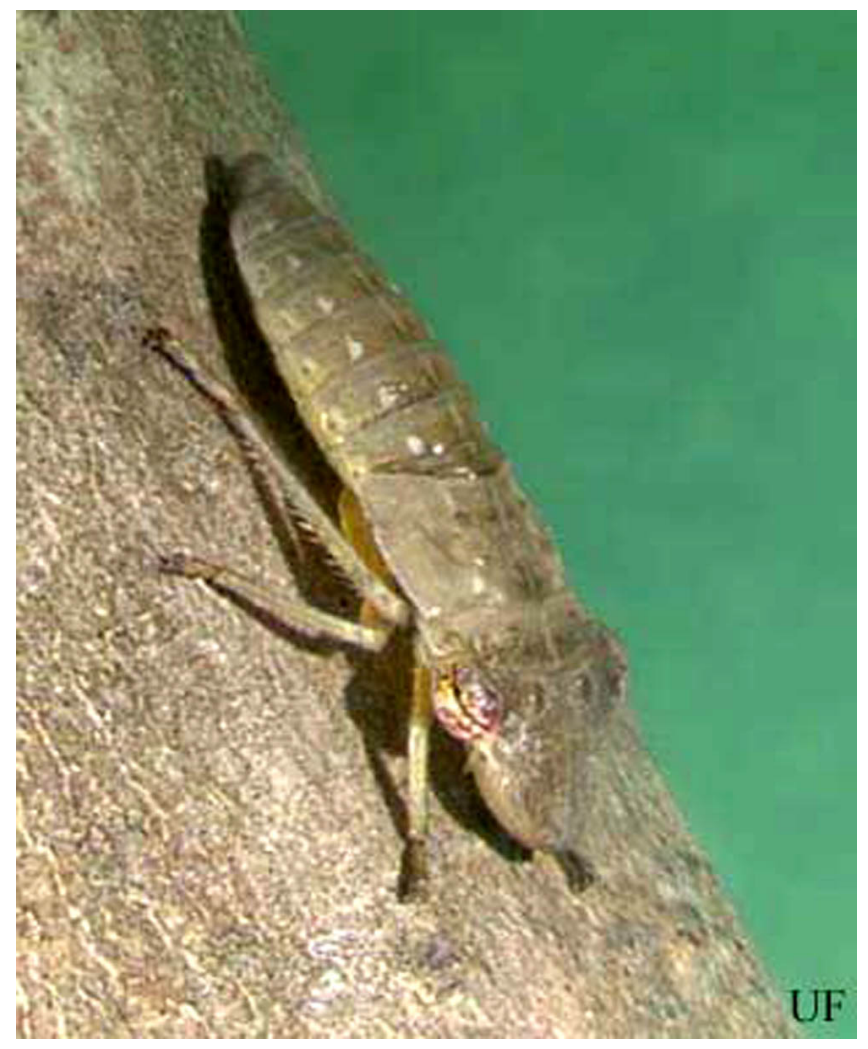

Figure 4. Nymph of the glassy-winged sharpshooter, Homalodisca coagulata (Say). Credits: Tracy Conklin, University of Florida

lays her eggs, she covers them with a white material scraped from deposits on her fore wings. This white powder is termed brochosomes, consisting of intricately structured hydrophobic particles. Brochosomes are produced in specialized secretory segments of the malphigian tubules, and are excreted by leafhoppers to cover their bodies and egg masses. 


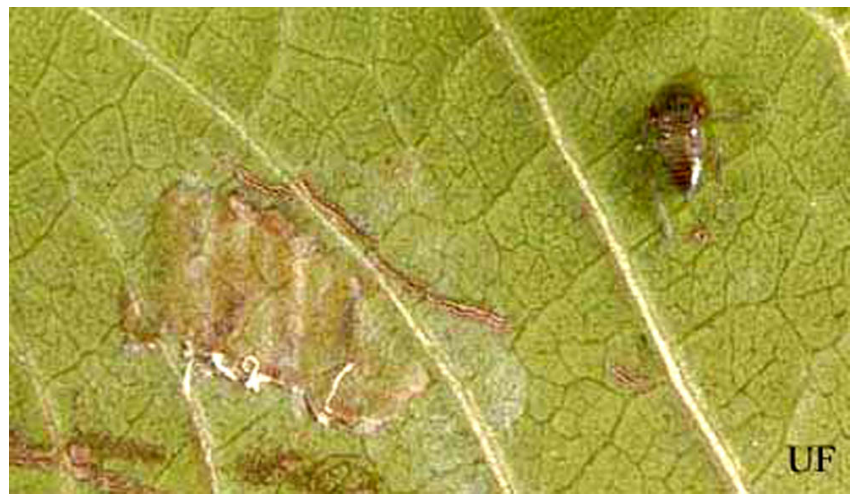

Figure 5. Neonate nymph and egg mass of the glassy-winged sharpshooter, Homalodisca coagulata (Say). Credits: Tracy Conklin, University of Florida

However, brochosomes are not produced in the same way at all stages of the life cycle. Females, like males and nymphs of $H$. coagulata and other species of the tribe Proconiini, produce spherical brochosomes until they have mated, at which time they begin to make rod-shaped brochosomes for the covering of egg masses (Rakitov). Spherical brochosomes are only used for covering the integument after ecdysis. Development is hemimetabolous. Populations reach their peak around the summer months, and begin to decline late August. As winter approaches, adults migrate into forest areas and undergo incomplete hibernation in wait of spring. Mating occurs in the spring and summer.

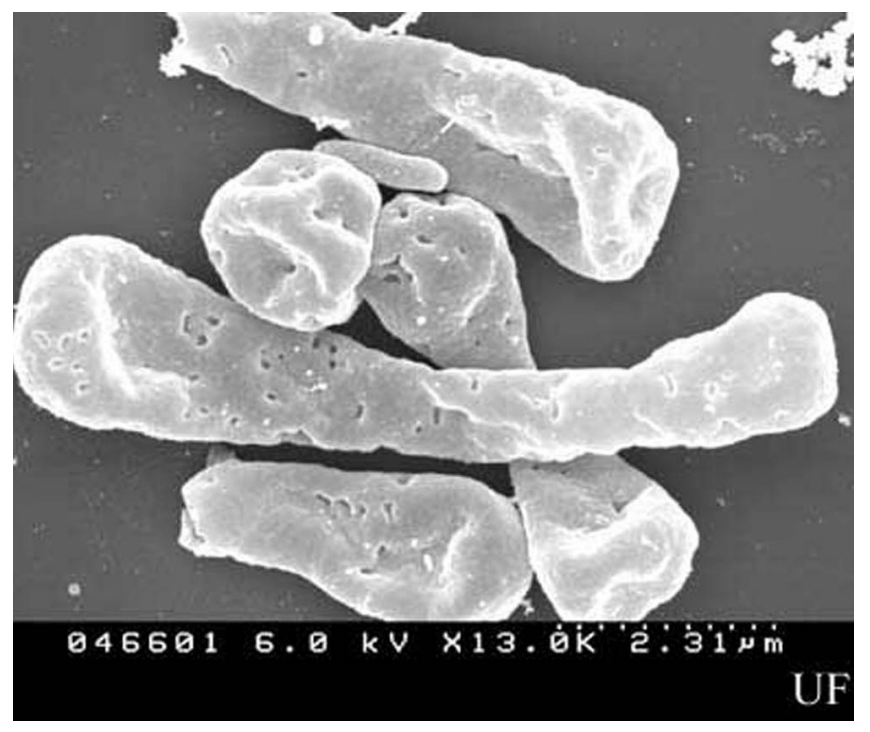

Figure 6. SEM of brochosomes of the glassy-winged sharpshooter, Homalodisca coagulata (Say). Credits: Tracy Conklin, University of Florida

\section{Feeding}

$H$. coagulata feeds in the xylem, the water conducting tissue of both herbaceous and woody plants. Its known host range is vast, including more than 100 plant species (Turner and Pollard). Preferred plants depend on the season and locality, but, in general, the preferred species include crape myrtle, citrus, and holly. Glassy-winged sharpshooters tend to feed on last-year's growth and meristematic growth (Mizell and French), and excrete copious amounts of liquid as they feed. The sharpshooters ingest 100 to 300 times their dry body weight in xylem fluid per day, and in large populations, their high volume of excreta ("leafhopper rain") can become a problem, leaving white residue on leaves. Due to the dilute nutrient content of xylem fluid, glassy-winged sharpshooters must have special adaptations to obtain the proper balance of nutrients. Feeding times are thus orchestrated to coincide with the period of peak nutrient content in the host plant (Brodbeck et al.). Also, a specialized structure of the digestive system known as the filter chamber recycles the ingested fluid and improves nutrient absorption, resulting in excreta that is $99.9 \%$ water, inorganic ions, and ammonia, the sharpshooter's excretory form of nitrogen.

\section{Vector Status}

While feeding from an infected plant, the glassy-winged sharpshooter acquires the bacterium Xylella fastidiosa. The bacterium establishes itself in the mouthparts of the leafhopper, on the floor of the cibarium, the apodemal groove of the diaphragm, and the walls of the precibarial area both above and below the precibarial valve- attaching itself to these surfaces (Brlansky et al.). Nymphs that acquire $X$. fastidiosa loose their ability to transmit the disease after molting. (Brlansky et al.)

Transmission takes place during the seasonal flights of the sharpshooters, when there are large numbers of leafhoppers. In California, the incidence of $X$. fastidiosa in field populations of other species of leafhoppers has been observed to be as high as $18.6 \%$ (Frietag and Frazier) during most of the year. The incidence of $X$. fastidiosa in field populations of the glassy-winged sharpshooter in California is not 


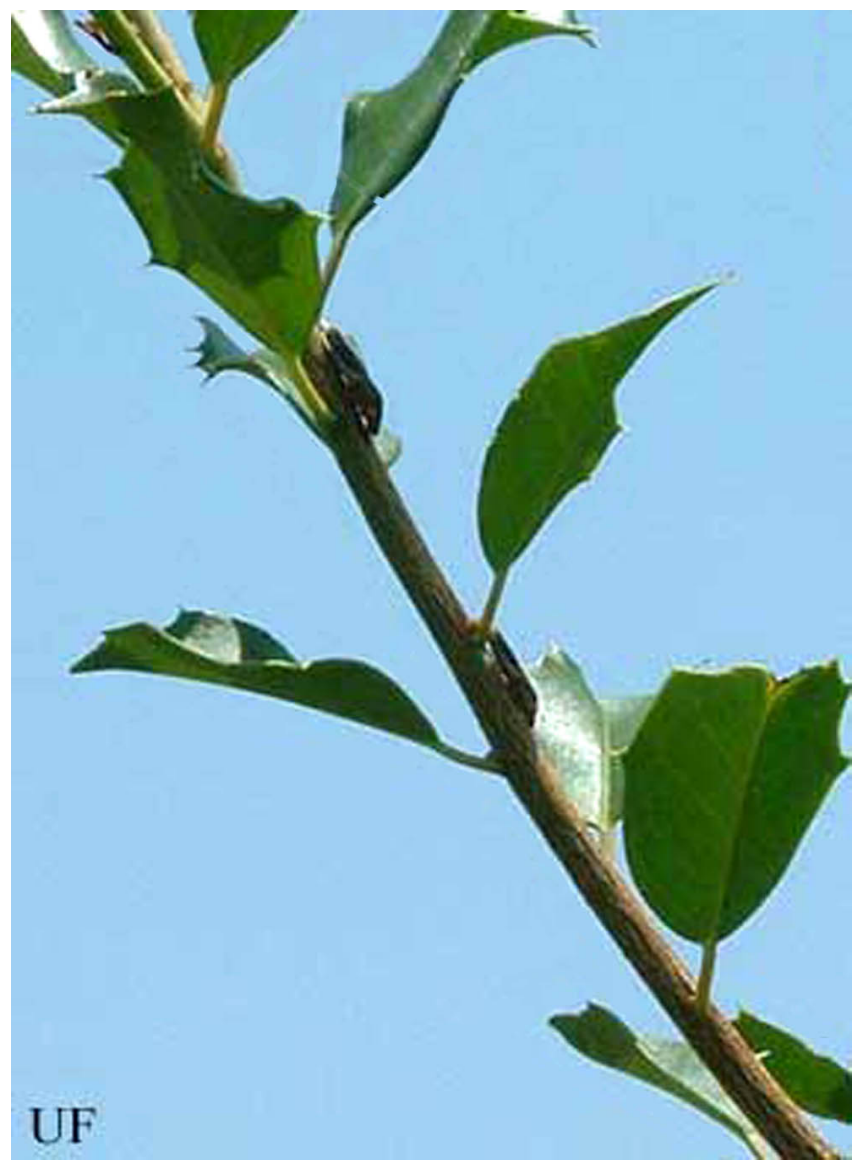

Figure 7. Adult glassy-winged sharpshooters, Homalodisca coagulata (Say), feeding on holly. Credits: Tracy Conklin, University of Florida

well-studied. In Florida, however, natural infectivity of the glassy-winged leafhopper is very low (Alderz and Hopkins). As to the vector efficiency of the glassy-winged sharpshooter, Costa et al. (2000) found that, under ideal conditions, $83 \%$ of oleander plants each exposed to a single leafhopper carrying $X$. fastidiosa became infected with the bacterium.

For information past and current glassy-winged sharpshooter activity in California, see the California Farm Bureau Federation glassy-winged sharpshooter Web site (http://www.cfbf.com/issues/gwss/).

\section{Management}

Insecticidal: Effective techniques for leafhopper management remain somewhat elusive. Conventional control methods, using general insecticides, have been effective in eliminating the sharpshooter from vineyards and orchards. Bethke, Blua, and Redak (2001) have recently tested the use of several kinds of insecticides and different application methods, finding that transmission of oleander leaf scorch was blocked by foliar-applied acetamiprid and soil-applied imidacloprid and thiamethoxam.

Biological: In the area of biological control, a species of parasitic wasp (Gonatocerus triguttatus) has been introduced into California in an effort to control the early spring generation of the sharpshooter. The tiny wasp from Texas and Northern Mexico is an egg parasite of the sharpshooter, laying its eggs within the eggs of the sharpshooter (Triapitsyn and Phillips). Research is also underway to promote the use of entomopathogens such as Hirsutella sp., a fungus that is known to affect sharpshooters in the southeastern United States.

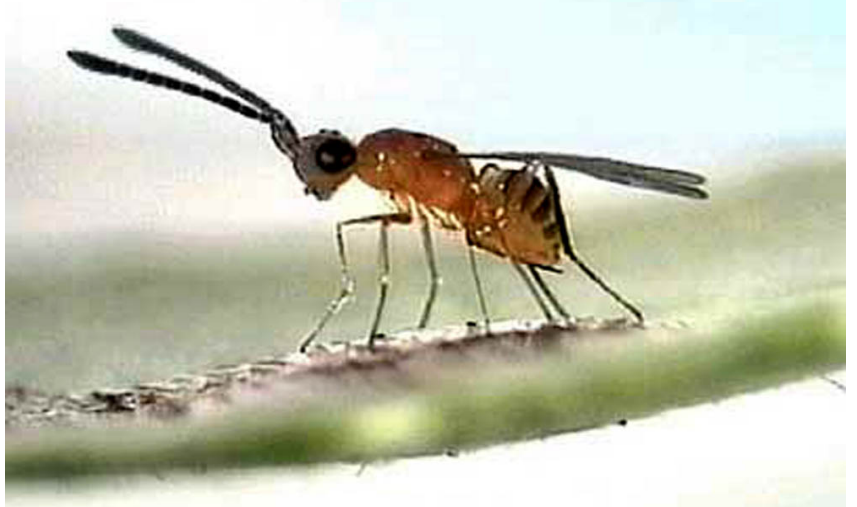

Figure 8. Adult Gonatocerus triguttatus, a wasp parasitoid, lays its eggs in glassy-winged sharpshooter eggs embedded in a leaf. Credits: Reyes Garcia III, USDA

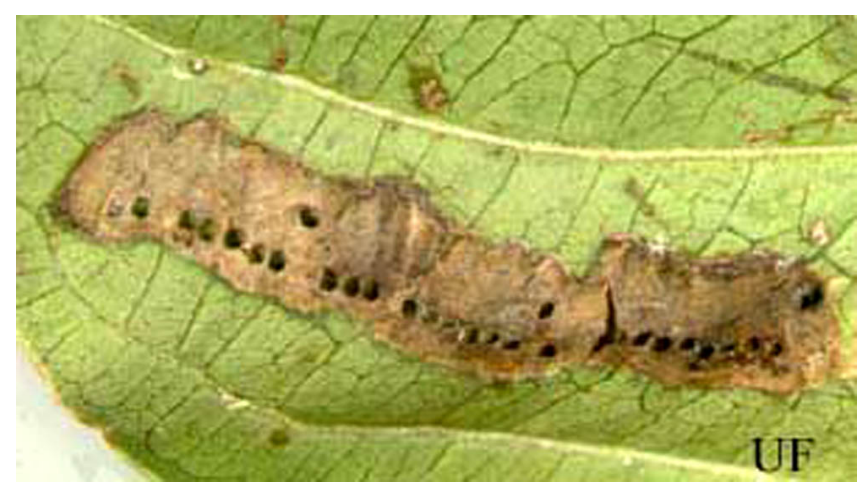

Figure 9. Parasitized egg mass of the glassy-winged sharpshooter, Homalodisca coagulata (Say). Credits: Tracy Conklin, University of Florida

Cultural: Cultural control methods include removing other host plants such as weeds and fruit trees from the area. Finding X. fastidiosa-resistant rootstocks may also be a possible way of limiting the 
affect of the disease, avoiding the problem of the leafhopper's presence altogether. While wine grapes (Vitis vinifera) are susceptible to Pierce's disease, Muscadine grapes are resistant, and may someday provide resistant rootstocks for the grape industry.

\section{Management links:}

CA Department of Food and Agriculture Pierce's disease control program (http://www.cdfa.ca.gov/gwss/)

University of California - Riverside glassy-winged sharpshooter brochure (http://info.ucr.edu/gwss/GWSS_brochure.pdf)

University of California - Integrated Pest Management of the Glassy-winged Sharpshooter and the Diseases it Transmits Workgroup (http://gwss.ucanr.org/)

University of California - Xylella fastidiosa Web site (http://www.cnr.berkeley.edu/xylella/)

\section{Selected References}

Alderz WC, Hopkins DL. 1979. Natural infectivity of two sharpshooter vectors of Pierce's disease of grape. Journal of Economic Entomology 72: 916-919.

Bethke JA, Blua MJ, Redak RA. 2001. Effect of selected insecticides on Homalodisca coagulata (Homoptera: Cicadellidae) and transmission of oleander leaf scorch in a greenhouse study. Journal of Economic Entomology 94: 1031-1036.

Brlansky RH, Timmer LW, French WJ, McCoy RE. 1983. Colonization of the sharpshooter vectors Oncometopia nigricans and Homalodisca coagulata, by xylem-limited bacteria. Phytopathology 75 : 530-535.

Brodbeck BV, Mizell RF, Andersen PC. 1992. Physiological and behavioral adaptations of three species of leafhoppers in response to the dilute nutrient content of xylem fluid. Journal of Insect Physiology 39:73-81.

Costa HS, Blua MS, Bethke JA, Redak RA. 2000. Transmission of Xylella fastidosa to oleander by the glassy-winged sharpshooter, Homalodisca coagulata. HortScience 35: 1265-1267.

Frietag JH, Frazier NW. 1954. Natural infectivity of leafhopper vectors of Pierce's disease virus of grape in California. Phytopathology 44: 7-11.

Mizell RF, French WJ. 1987. Leafhopper vectors of phony peach disease: feeding site preference and survival on infected and uninfected peach, and seasonal response to selected host plants. Journal of Entomological Science 22: 11-22.

Rakitov RA. 2002. What are brochosomes for? An enigma of leafhoppers (Hemiptera, Cicadellidae). Denisia 4: 411-432.

Sorensen JT, Gill RJ. 1996. A range extension of Homalodisca coagulata (Say) (Hemiptera: Clypeorrhyncha: Cicadellidae) to southern California. Pan-Pacific Entomologist 72: 160-161.

Triapitsyn SV, Phillips PA. 2000. First record of Gonatocerus triguttatus (Hymenoptera: Mymaridae) from eggs of Homalodisca coagulata (Homoptera: Cicadellidae) with notes on the distribution of the host. Florida Entomologist 83: 200-203.

Turner WF, Pollard HN. 1959. Life histories and behavior of five insect vectors of phony peach disease. USDA Technical Bulletin 1188. 28p. 